\title{
カージングローラー設計上の一提案
}

名古屋工業大学 原川 和 久(会員)

\section{An Approach to the Design of Carding Roller}

\section{Kazuhisa Harakawa}

Nagoya Institute of Technology, Shcwa-ku, Nagoya

\section{1. まえがき}

2 つのカージング ローラー間の 緘維移動において, ローラー表面速度比 $K_{V}$ 之絨維移動率 $P$ の関係は， 1 本の繊維移動に注目して限界角度差 $₫ \Delta \phi 〕$ を規定するて

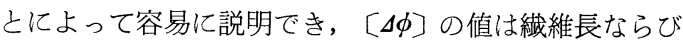
に繊維の種類によらず（供給繊維が少ないという条件下 ）ほぼ一定值を示すことがわかった1). 一方長さの異な った混合繊維体の 2 つのカージング ローラー間の移動 において，適当な機械条件下では混合繊維が長さ別に分 類される傾向がみられることは先に報告した2².

このような現象を考慮すると，カージングローラー に関してはまだまだ多くの問題が残されているし，その 利用価值む拡大されうるものと考えられる．乙のような 観点からすれば， カージング ローラーを利用しようと するとき， $P$ の $K_{V}$ に対するパターンが，繊維長 $(l)$, 繊維の種類, メタリック ワイヤーの針角度 $(\Theta, \theta)$, ローラー半径 $(R, r)$ などによってどのように变わるか を系統的に知ることは重要である。しかし，乙れを実験

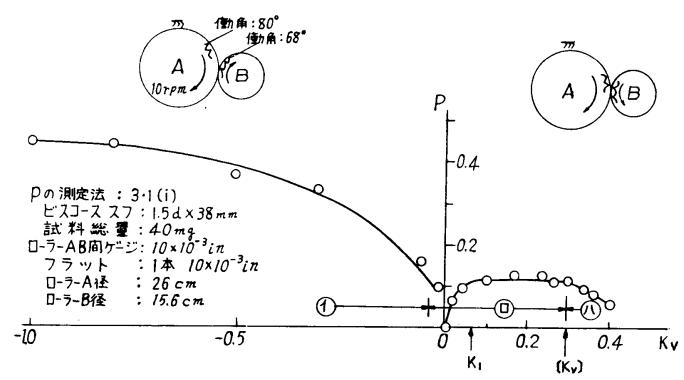

（第 1 図）繊維移動率 $P$ のローラー表面速度比 $K_{V}$ に 対する変化パターン（文献 1）上り転載） $P$ の値は $K_{V}$ が $K_{1}$ になるまで増加し， $K_{1}$

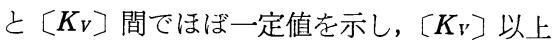
で減少を始める。
的知ることはぼう大な実験を必要とし，ほとんど不可 能であろう．ここに理論的な推定が是非必要となる。本 報はその糸口として, 前記繊維移動パターンと繊維条件 および機械条件の関係を, 文献 1）の理論に基づいて検 討しょうとしたあのである.

\section{2. 文献 1）の実験結果の検討}

$K_{V}$ の増加につれて $P$ が減少しはじめる $K_{V}$ の值 $\left\lceil K_{V} 〕\right.$ に注目する (第 1 図参照). 文献 1) の実験結果 を $K_{V} 〕$ と $l / r$ との関係として整理すると第 2 図にな

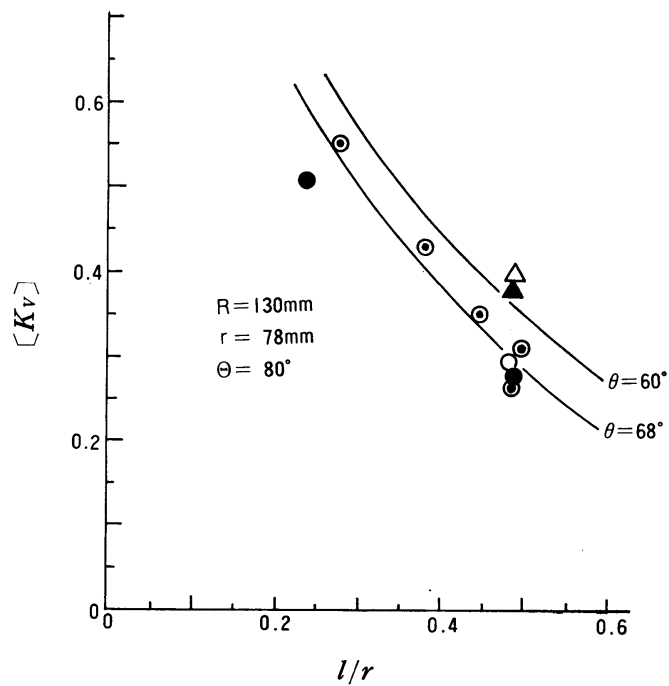

（第 2 図）文献 1）の実験値の整理

丸印は $\theta=68^{\circ}$, 三角印は $\theta=60^{\circ}$ のときの実験値.

A, はポリエステル スフ $1.25 \mathrm{~d}, \odot$ はビスコー ス スフ $2 \mathrm{~d}$.

$\triangle, \bigcirc$ はビスコース スフ $1.5 \mathrm{~d}$.

文献 1）第 3 表のうち ビスコース スフ $2 \mathrm{~d} \times 22 \mathrm{~mm}$ 〜39mm，ビスコース スフ $1.5 \mathrm{~d}$ および，第 5 表全 部の実験值を整理している. 
り，両者の間にある関係があることが認められる。この ことから任意の $l / r$ に対する $\left[K_{V}\right] の$ 值を知るために は次の方法が考えられる.

文献 1）の理論式(2)，(3)式を(2)'，(3)'式に変形する. ついで $\Delta \phi$ を限界角度差 $[\Delta \phi]$ (実験で求めた値の平均 值を考える）に選び，任意の $l / r$ に対して(2)'，(3)'式を

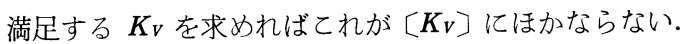

$$
\begin{aligned}
\left(\frac{l}{r}\right)^{2}= & \left\{\frac{R}{r}\left(1-\cos \omega_{A} t\right)+\left(1-\cos \frac{R}{r} K_{V} \omega_{A} t\right)\right\}^{2} \\
& +\left\{\frac{R}{r} \sin \omega_{A} t-\sin \frac{R}{r} K_{V} \omega_{A} t\right\}^{2} \cdots \cdots(2)^{\prime} \\
\Delta \phi=\theta & -\theta-\omega_{A} t\left(1+\frac{R}{r} K_{V}\right)
\end{aligned}
$$

いま $R=130 \mathrm{~mm}, \quad r=78 \mathrm{~mm}, \quad \Theta=80^{\circ}, \quad \theta=60^{\circ}$ および $68^{\circ}$ とし, また計算の都合上 $[\Delta \phi]=-20^{\circ}\left(\omega_{A}\right.$ の值に よって線図は変わらない）として任意の $l / r$ に対する $\left[K_{V}\right]$ を求好之第 2 図の実線（以後 $l / r \sim\left[K_{V}\right]$ 線図 とよぶ）になる．線図は実験値の傾向をよく示している ことがわかる。

多くの機械条件に対して, $l / \boldsymbol{r} \sim\left[K_{V}\right]$ 線図が示され ればカージング ローラーの設計上有効な資料となる. 以下とのととについて説明する.

\section{3. $\boldsymbol{l} / \boldsymbol{r} \sim\left[\boldsymbol{K}_{V}\right]$ 線図について}

すべての機械条件に対して $l / r \sim\left[K_{V}\right]$ 線図を描くた めには，すべての機械条件に対して〔 $\Delta \phi 〕 の$ 実験的検討 が必要である。乙れは前述のと扔り不可能に近い，そこ

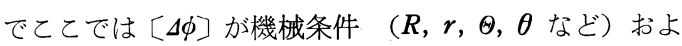
び䋳維条件によらず一定であると仮定して $l / r \sim\left[K_{V}\right]$ 線図を求めてみた（第 $3 ， 4$ 図の実線）．乙れから機械条 件によって紪維移動がごのように影響されるかの大ざっ

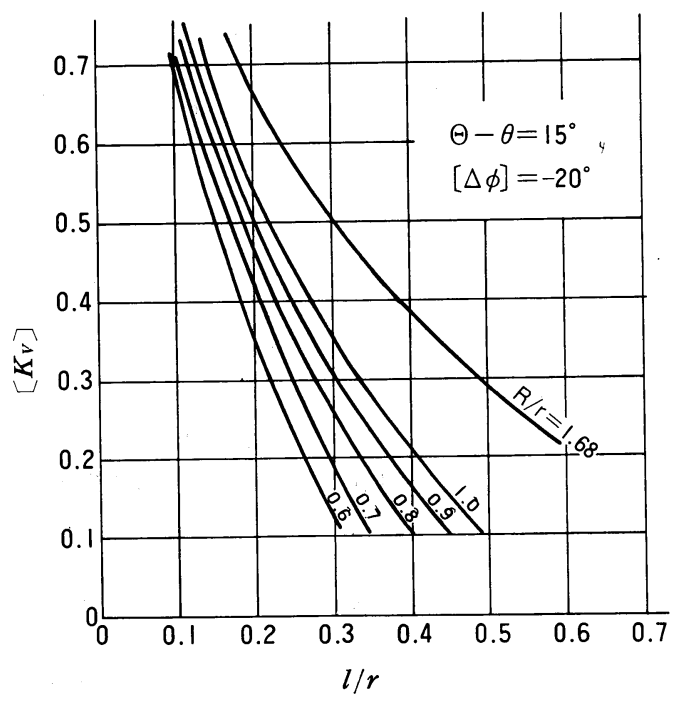

(第3図) $l / r \sim\left[K_{V}\right]$ 線図

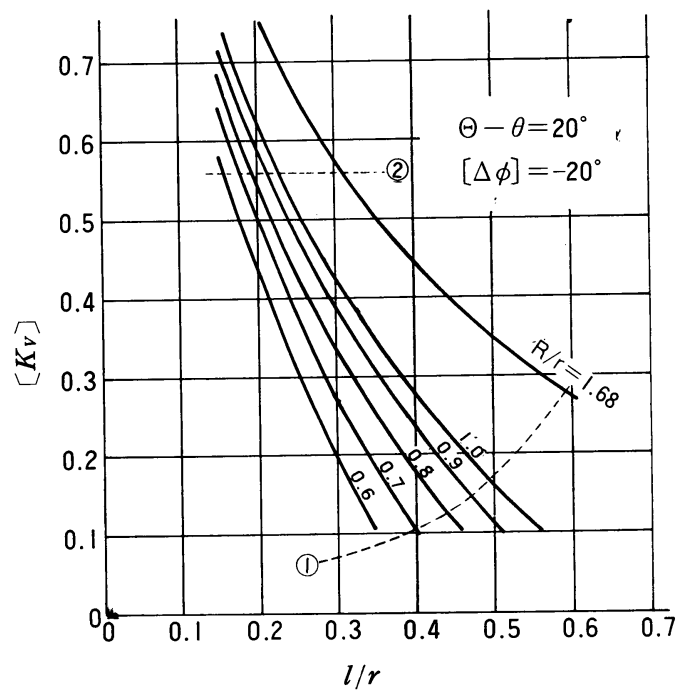

(第 4 図) $l / r \sim\left[K_{V}\right]$ 線図

ぱな見当がつき，以後に試作するカージング ローラー 諸元を决定する足掛かりとするととができる. 第3，4眓 において〔 $\Delta \phi]$ は $-20^{\circ}$ とした. $R / r$ は 0.6〜 1.68 (綿 用実用カードではシリンダーとドッファー芼の比は 1.85 程度）の間を適当に選んだ. 針角度は $\Theta-\theta$ で示し, 実 用も考慮して $15^{\circ}$ (第 3 戝), $20^{\circ}$ (第 4 図）亡した.

本線図は $\left[K_{V}\right]$ のみ注目し， $K_{V}$ が 0 付近での繊維 移動の特異性などについての考慮がなされていない。こ れを次に例をあげて説明する。

i ）カージング力不足による〔 $\left.\boldsymbol{K}_{\boldsymbol{V}}\right]$ の制限

第 4 図に抽い, $R / r=1.68, l / r=0.20$ とき $\left[K_{V}\right]$ はほぼ0.75である.すなわちこのような $R, r, l$ の条件 では $K_{V}$ が 0.75 になるで $P$ の減少は起こらないこと になる。しかし実際にはこのように $K_{V}$ が大きくなる と, カージング力が不足して繊維がローラーB（文献1） 第 1 図参照）に把握されにくくなることが予測される. 第 2 図において $l / r=0.245$ のときの〔KV】の実験值が $l / r \sim\left[K_{V}\right]$ 線図より小さくなったのはこのような原因 によるあの之考えられる. すなわち第 4 図の破線(2)で示

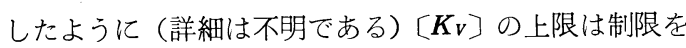
受けるあのと考えられる.

ii） $K_{1}$ (第 1 図参照) による制限

文献 1）の実験から， $K_{1}$ の值を表に示すと第 1 表に なる、表からわかるように，抱合性の大きい䋊維ほど $K_{1}$ の値は大きくなるようである. またポリエステル ス フの場合， $K_{1}$ の值が全般に小さいから繊維長による影 響を見い出すことはできないが，ビスコース スフの場 合には長繊維ほど $K_{1}$ の值は大きくなるといえる.

さて第 4 図において，たとえば $R / r=1.0, l / r=0.56$ のとき〔KV]は0.1である. いま取り扱っている繊維が 
(第 1 表)

\begin{tabular}{|c|c|c|}
\hline 繊 維 の 種 & 類 & $K_{1}$ \\
\hline \multirow{2}{*}{ ビスコース スフ $1.5 \mathrm{~d}$} & $19 \mathrm{~mm}$ & $0.1 \sim 0.15$ \\
\hline & $38 \mathrm{~mm}$ & $0.15 \sim 0.18$ \\
\hline \multirow{2}{*}{$\begin{aligned} \text { ポリエステル スフ } & 1.25 \mathrm{~d}\end{aligned}$} & $19 \mathrm{~mm}$ & $0.1 \sim 0.12$ \\
\hline & $38 \mathrm{~mm}$ & 0.1 以下 \\
\hline
\end{tabular}

$K_{1}$ については第 1 図参照

実験機諸元
$R: 130 \mathrm{~mm}$
$r: 78 \mathrm{~mm}$
$\theta: 80^{\circ}$
$\theta: 68^{\circ}$

ビスコース スフよのうに抱合性の大きいあのであれば, $\left[K_{V}\right]<K_{1}$ となることが容易に起とりうる. このような 場合には $\left[K_{V} 〕 は K_{1}\right.$ に制限される. すなおち一般に

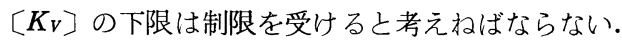

この制限は i ）の場合と同様不明であるが，第 1 表の ビスコース スフの $K_{1}$ の值が絨維長に依存していると と，また繊維が両ローラーに分離する付近のローラー間
の空間之繊維長の相乗効果を考慮すると，第 4 図破線(1)

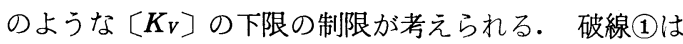
繊維の種類で大きく変わることは第 1 表から明らかであ る.

\section{4. まとめ}

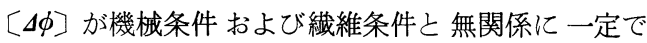
あると仮定して, カージング ローラー半径比 $R / r$, 緎 維長とカージング ローラー半径比 $l / r$, ならびにメ夕

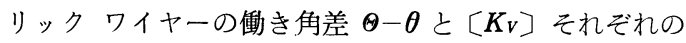
相互関係を理論的に検討してれを図式化した。これが実 用できるためには，多くの実証が必要である.

なお本研究の一部は日本繊維機械学会第24回年次大会 で発表した.

\section{参考文献}

1）原川, 田中；絨機誌，24，T95（1971）

2）原川, 鈴木; 日本緎維機㭜学会東海地方大会 講演前 刷 P9 (1970-11)

（昭和 46 年 6 月 16 日 受理） 